\author{
Yevheniia Yu. Nikiforova \\ ORCID ID: 0000-0001-6249-9781 \\ Olha O. Havryliuk \\ ORCID ID: 0000-0002-0365-3248 \\ Elizaveta A. Galitska \\ ORCID ID: 0000-0002-0859-1322
}

\title{
PERFUME AND COSMETIC NAMING REGISTER AS THE REFLECTION OF SOCIAL STRATIFICATION
}

\begin{abstract}
The article deals with the perfume and cosmetic naming register investigation in the aspect of its function as a source of lexical units used for further formation of naming units. The objects of this research are basic naming components that are distinguished within the structure of naming complexes represented in perfume and cosmetic goods. The naming integrated complex which represents the perfume and cosmetic name consists of four nominative components functioning in the mutual correlation. The initial position is connected with the A-brand component, the second position correlates with the B-basic component, the third one is the C-generic name component and the last is the D-functional-descriptive component. The leading position belongs to the B-component as a bearer of the basic name representing the corresponding item on the consumer goods market. The market segment correlates with consumers' social and economic status mutually. The market segment net functions as a factor indicating and underlying social stratification in the perfume and cosmetic naming space. The goods names that belong to the natural language according to the source of their origin are divided into two substantial groups (names of onym origin, names of appellative origin). The first group is formed involving transonymisation, the second one includes onymisation and is divided into various lexico-semantic groups. The involvement of anthroponym and toponym registers for creating perfume names is based on the basic knowledge of the recipients. The appellative naming register is an inexhaustible source for inventing perfume names. The differentiation of the naming register in its appellative part led to the separation of nine lexicogrammatic groups. Borrowings create the third source of perfume names. The fourth source of perfume and cosmetic names comprises artificially created words. If the perfume and cosmetic naming integrated complex consists of four components, the perfume and cosmetic naming register consists of four groups as well. These groups were distinguished according to the ways of name creation. The social stratification is reflected in the register in various
\end{abstract}


ways. The first is an extralinguistic one according to three market segments. This way correlates with the A-brand component. The second is a linguistic way and correlates with the B-basic component. The linguistic way of social stratification is divided into explicit and implicit.

Keywords: anthroponym, appellative, artificially created word, borrowing, onym, onymisation, social stratification, transonymisation.

Information about the authors: Nikiforova Yevheniia Yuriivna - PhD in English Philology; Associate Professor at the Department of English Philology and Intercultural Communication; Educational and Scientific Institute of Philology; Taras Shevchenko National University of Kyiv.

Havryliuk Olha Oleksandrivna - PhD in English Philology; Assistant Professor at the Department of English Philology and Intercultural Communication; Educational and Scientific Institute of Philology; Taras Shevchenko National University of Kyiv.

Galitska Elizaveta Anatoliivna - PhD in English Philology; teacher of English; Kyiv Gymnasium №86 "Consul".

E-mail:elt.nikiforova@gmail.com; oliagavr@gmail.com; liza-g@ukr.net

Нікіфорова С.H.

ORCID ID: 0000-0001-6249-9781

Гаврилюк 0.0 .

ORCID ID: 0000-0002-0365-3248

Галицька $\boldsymbol{C . A . ~}$

ORCID ID: 0000-0002-0859-1322

\section{ПАРФУМЕРНО-КОСМЕТИЧНИЙ НОМІНАТИВНИЙ РЕГІСТР ЯК ВІДОБРАЖЕННЯ СОЦІАЛЬНОЇ СТРАТИФІКАЦЇ̈}

Анотація. Стаття присвячена питанню парфумерно-косметичної номінації та сфокусована саме на номінативному простір-регістрі, що розглядається як функиіональне джерело для наступного формування номінативних одиниць-назв. Об'єктом прискіпливої уваги $\epsilon$ базові номінативні компоненти, що ідентифіковані в структурі номінативних компонентів, які репрезентують парфумернокосметичні товари. Номінативний інтегрований комплекс, який фактично репрезентує парфумерно-косметичну назву, складається з чотирьох номінативних компонентів, щзо тісно взаємопов'язані. Aбрендовий компонент посідає ініціальну позицію, друга позииія належить В-базовому компоненту, на третьому місиі $\epsilon$ С-родовий компонент. Ланцюг компонентів замикається Д-функиіональнодескриптивним. Домінуюча позиція належить В-компоненту як носію базового імені, яке репрезентує відповідний товар на споживчому товарному ринку. Ринковий сегмент корелює із соиіально-економічним 
статусом споживачів. Мережа ринкового сегменту функиіонує як фактор, щзо вказуе $i$ підкреслюе сочіальну стратифікацію $у$ парфумерно-косметичному номінативному просторі. Товарні назви, щуо належать до природньої мови, розподіляються на дві основні групи відповідно до джерела їхнього походження: слова онімного та апелятивного походження. Перша група сформована завдяки прочесу трансонімізації. Друга утворилася завдяки онімізації $i$, у свою чергу, розмежована на лексико-семантичні групи. Використання антропонімічних і топонімічних регістрів для створення парфумерних назв трунтується на фонових знаннях реципієнтів-споживачів. Апелятивний номінативний регістр є невичерпним джерелом для створення парфумерних назв. Диференціація номінативного регістру $в$ його апелятивній частині спричиняє виокремлення дев'яти лексикосемантичних груп. Запозичення вказують на третє джерело парфумерних назв, а итучно утворені слова свідчать про наявність четвертого джерела парфумерно-косметичних назв. Якщо парфумерно-косметичний інтегрований номінативний комплекс складається з чотирьох компонентів, у свою чергу, парфумернокосметичний номінативний регістр теж складається з чотирьох груп. Ці чотири групи були виокремлені виходячи із способів формування назв. Сочіальна стратифікація відображена в регістрі у різний спосіб. Першим є екстралінгвістичний; він відповідає наявності трьох ринкових сегментів. Цей спосіб корелює з А-брендовим компонентом. Другим $\epsilon$ лінгвістичний, щуо корелює $з$ В-базовим компонентом. У свою чергу, лінгвістичний спосіб репрезентації сочіальної стратифікацї розмежовується на експліцитний та імпліичитний.

Ключові слова: антропонім, апелятив, запозичення, онім, онімізація, соціальна стратифікація, трансонімізація, иттучно утворене слово.

Інформація про авторів: Нікіфорова Свгенія Юрївна - кандидат філологічних наук; доцент кафедри англійської філології та міжкультурної комунікації; Навчально-науковий інститут філології; Київський національний університет імені Тараса Шевченка.

Гаврилюк Ольга Олександрівна - кандидат філологічних наук; асистент кафедри англійської філологї та міжкультурної комунікації; Навчально-науковий інститут філологї; Київський національний університет імені Тараса Шевченка.

Галиџька Слизавета Анатоліївна - кандидат філологічних наук; вчитель англійської мови; Киїська гімназія №86 "Консул".

Електронна адреса: elt.nikiforova@gmail.com; oliagavr@gmail.com; lizag@ukr.net 


\title{
Никифорова Е.Ю.
}

ORCID ID: 0000-0001-6249-9781

\author{
Гаврилюк О.A.
}

ORCID ID: 0000-0002-0365-3248

Галицкая Е.A.

ORCID ID: 0000-0002-0859-1322

\section{ПАРФЮМЕРНО-КОСМЕТИЧЕСКИЙ НОМИНАТИВНЫЙ РЕГИСТР КАК ОТРАЖЕНИЕ СОЦИАЛЬНОЙ СТРАТИФИКАЦИИ}

\begin{abstract}
Аннотация. Статья связана с проблемой парфюмернокосметической номинации и сосредоточена на номинативном регистре, который рассматривается как функциональный источник для последующего формирования номинативных единиц. Объектом особого внимания являются базовые номинативные компоненты, которые идентифицированы в структуре номинативных комплексов, которые представляют парфюмерно-косметические товары. Номинативный интегрированный комплекс, представляющчий парфюмерно-косметическое название, состоит из четырех номинативных компонентов, функиионирующих в тесном взаимодействии. А-брендовый компонент занимает инициальное положение, на второй позиции находится В-базовый компонент, на третьем месте С-родовой компонент. Замыкает иепь компонентов Д-функционально-дескриптивный. Доминирующая позиция принадлежит В-компоненту как носителю базового имени, представляющий соответствующий товар на потребительском товарном рынке. Рьночный сегмент коррелирует с сочииальноэкономическим статусом потребителей. Сеть рыночного сегмента функционирует как фактор, указывающий и подчеркивающчий сочиальную стратификацию в парфюмерно-косметическом номинативном пространством. Товарные названия, принадлежащие естественному языку, разделень на две основные группь, в соответствии с источниками их происхождения (названия онимного и апелятивного происхождения). Первая группа сформирована благодаря процессу трансонимизаџии. Вторая образована под влиянием онимизации $u$, в свою очередь, разделена на различные лексико-семантические группь. Использование антропонимического и топонимического регистров для создания парфюмерных названий базируются на фоновых знаниях реципиентов-потребителей. Апелятивный номинативный регистр является неисчерпаемым источником для создания парфюмерных названий. Дифференциачия номинативного регистра в его апелятивной части приводит $к$ выделению девяти лексико-семантических групп. Заимствования
\end{abstract}


Актуальні проблеми української лінгвістики: теорія і практика

создают третий источник парфюмерных названий. Искусственно созданные слова формируют четвертый источник парфюмернокосметических названий. Если парфюмерно-косметический интегрированный номинативный комплекс состоит из четырех компонентов, то, в свою очередь, парфюмерно-косметический номинативный регистр состоит также из четырех групп. Эти четыре группь были выделены исходя из способов формирования названий. Социальная стратификачия отображена в регистре различныли путями. Первый является экстралингвистическими, в соответствии с тремя рыночными сегментами. Этот способ коррелирует с А-брендовым компонентом. Вторым путем является лингвистический, коррелирующий $c$ В-базовым компонентом. Лингвистический путь репрезентации социальной стратификации разделен на эксплицитный и имплицитный.

Ключевые слова: антропоним, апелятив, заимствование, искусственно созданное слово, оним, онимизация, социальная стратификация, трансонимизаџия.

Информация об авторах: Никифорова Евгения Юрьевна кандидат филологических наук; доцент кафедры английской филологии и межкультурной коммуникации; Учебно-научныий институт филологии; Киевский национальныий университет имени Тараса Шевченко.

Гаврилюк Ольга Александровна - кандидат филологических наук; ассистент кафедры английской филологии и межкультурной коммуникации; Учебно-научный институт филологии; Киевский национальный университет имени Тараса Шевченко.

Галиикая Елизавета Анатолиевна - кандидат филологических наук; учительница английского языка; Киевская гимназия №86 "Консул".

Электронный адрес: elt.nikiforova@gmail.com; oliagavr@gmail.com; liza-g@ukr.net

The problem of naming phenomena and objects surrounding the person and creating the person's environment is still a fundamental cornerstone of current linguistics. It was ancient time that there was a thesis about names that were recognized as images of objects. An individual who knows names can comprehend the belonging of these names. A person who knows the names is able to be aware of the objects. The name correctness lays in the fact that the correct name indicates the individual features of the object. The objects themselves have their own stable identity without any correlation with us and independently from us. The nominator gives names to objects. This 
nominator should comprehend in sounds and syllables the individual name that is connected with nature. It is not a simple case for occasional and nonprofessional people to give names. Cratil is right saying that objects have names from nature, and it is impossible for anybody to be a nominator-professional. It is possible only for people who pay attention to an individual name determined by nature and who may realize that image in letters and syllables [6, p. 481]. Plato's etymologies are built from the point of correlating the name with the features of the object. Plato's etymology system is a system of rules and, if these rules are applied, it is possible to create real names [7, p. 49].

The aim of the article is the study of the naming register in the aspect of its function as a source of lexical units using for further formation of perfume and cosmetic names. The purpose is connected with finding out the ways of social stratification reflection in the boundaries of perfume and cosmetic naming complexes. The topicality of research is connected with the difficulties the researchers face trying to grasp all varieties and variations of perfume and cosmetic productions. There are no attempts to represent the social stratification in the perfume and cosmetic naming space. The object of the investigation is basic naming components which are separated within the structure of naming complexes represented in perfume and cosmetic goods. The subject of the investigation is the representation of social stratification by using the corresponding lexical units taken from the naming register.

Publication analysis. Social stratification reflection in the perfume and cosmetic naming space is based on the extralinguistic specification. The present-day perfume and cosmetic goods market is understood as a pyramid structure where its top represents the cluster of selective perfumes. The pyramid food represents the mass perfume market where the leading position belongs to global companies (L'Oréal, $P \& G$ ). Globalization and attendant processes of simplification and unification influence the art of aroma creation. These processes caused the production of global perfume goods when social values are sent using "megabrands" and the 
representation of new beauty traditions [3, p. 899-900]. Perfume and cosmetic goods may be classified on the points of price and quality: middle class, cheapest, mass consumption products (Ruby Rose, Kiki); the consumers of this class goods are people with income of under the middle level. Mass Market is the products of brand levels of consumers (Max Factor, L'Oréal, Lumene, Oriflame, Avon), the consumers of that group goods are people with a middle level of income and higher. Lux class is represented with selective marks which are distinguished with a high quality and price. They are manufactured by perfumers' shops, perfumery and design companies (Cristian Dior, Chanel, Lancôme). The consumers of that class goods are people with a high level of income. Super lux class contains exclusive brands of perfume and cosmetic goods (La Prairie, Mikimoto Cosmetics). They have the highest prices, cannot be found in all shops with their consumers being people with a very high level of income [2, p. 37-38]. An incredible shift in the sphere of social and consumer traditions happened in the XX century. In fact, it was the XIX century's perfumers' dream about the possibility of consuming perfumes by broad social levels, classes and subclasses. That dream was realized due to the tendency of interacting with fashionable clothes and fragrance, the aroma when fashionable clothes needed a corresponding fashionable, powerful olfactory accessory using a collection of perfumes. Another factor that caused the creation of a new perfume market segment was a purely economic background. Fashion designers tried to find out new products which would be able to prevent the continuous pursuit of new brand changing and fix the obtaining of stable income irrespective of fashionable stylish tendencies. According to Euromonitor company investigations, it is shown that toilet water Adidas is becoming more and more popular brand in western Europe [10, p. 28]. Concerning the process of naming, it consists of two stages. The first stage includes naming properly or name invention while the second - juridical support. It includes checking the name used as a brand for other goods, services; and further document preparation with the following name registration. In particular, at the 
very end of XX century, investigations demonstrated the fact that about $60 \%$ of brand managers in the USA (the motherland of branding) believe that without any advertisement support the brand name itself may influence the selling volume [4, p. 71-72]. In 2007 Deborah Merskin presented the investigation results connected with the brand lipstick naming. There she observed textual properties and classification, grouping the names of these make-up goods. Having used the categorial analysis she singled out 14 classification groups such as colour, food, sex and romanticism, nature elements and minerals, emotions and their features, geographical names and toponyms, people, flowers, objects, dark side of existence (devil, witches, witchcraft), fine art and mass media, day and season divisions, birds and animals [5, p. 596-597]. M. Harrison, an outstanding American linguist-investigator of olfactory naming, speaking about perfume naming noticed, "The consumers are likely to have been abandoned for creating their own image situations using linguistic associations as reference-points" [1, p. 8].

Main information presentation. The naming integrated complex, which represents the perfume and cosmetic name in its completion and perfection, consists of four nominative components functioning in the mutual correlation. The initial position is connected with A-brand component (Paco Rabanne). The second position correlates with B-basic component (1 million). The third one is $\mathrm{C}$-generic-name-component (eau de toilette). The last is D-functional-descriptive component (vaporisateur spray). The leading position belongs to B-component that is a bearer of the basic name representing the corresponding article on the consumer goods market. It is B-basic component that is under the attention in the case of the perfume and cosmetic naming register investigation. The register is understood as a set of lexical units originated from a different source (onyms, appellatives, borrowings and artificially created words) and are used for creating B-basic components. The investigation of B-basic component formation is inextricably connected with $\mathrm{C}$-generic name component used to indicate the belonging of a certain article of a certain type. There are such types 
of goods as perfumes, toilet water, eau de cologne, mascara, eye shadow, lipstick, and lip gloss, nail polish, face foundation, face powder, blush. This goods chain finishes with nourishing face cream.

Social stratification factor may be formally correlated with A-brand component; A-component is an indirect indicator of perfume and cosmetic goods belonging to the definite market segment. Hence, the market segment correlates with the social and economic status of consumers. Having tried to avoid thorough differentiation and singling out all intermediate segments, this research grasps all the market structures as a set of three definite segments. The first (I) segment is associated with the most expensive goods marked with A-brand components such as Dior, Estee Lauder, Fendi, Gucci, Jean-Paul Gaultier, Kenzo, Paco Rabanne, Versace, Yves Rocher, Yves Saint Laurent. The second (II) one covers the middle-priced goods represented with A-brands, like Escauda, Fragrances of France, Lancôme, Perlier, Valentino, Victoria's Secret. The third (III) one correlates with the cheapest consumer commodities circulating and is marked with brand names AVON, Oriflame, Revlon. Three-segment net functions as a factor indicating and underlying social stratification in the perfume and cosmetic naming space.

The research of the perfume and cosmetic name corpus reveals that the goods names belonging to a natural language according to the sources of their origin are divided into two substantial groups:

(1) perfume and cosmetic names of onym origin;

(2) goods names of appellative origin.

The first group is formed involving the process of transonymisation. It causes the changes when one personal name becomes the source of another personal name. Within the second group we can observe onymisation when a common name is the source of a personal name. The perfume and cosmetic names having the onym register as a source grasp anthroponyms and toponyms. The second name group is composed involving different lexicosemantic groups of an appellative register united into corresponding thematic groups. 
The perfume subcorpus contains 676 names, there are 146 anthroponyms (95 names belong to the perfumes of the first segment; 37 names are connected with the second segment; 14 names - with the third one). The leading tendency of forming B-basic component is the involvement of family names, usually first names of owners of fashion houses. Anthroponyms involving them may create the whole B-component (Dolce and Gabbana (I)) or as a shortened variant (Dolce (I)). They may be the fragment of B-component (Dior Addict (I), Estee Lauder Pleasures Flower (I)). They may be the fragment of B-component which is mostly a borrowing (Miss Dior Cherie (I); Dior Homme Parfum (I); Bulgari pour Femme (I)). Naming synergy occurs when both anthroponyms and appellatives are used for B-basic component formation. The attractiveness of B-basic component is maintained when different sources of naming register are used. This type of naming practice happens in the perfume names of the first and partly the second segments (Narciso Rodrigues (II), Narciso Rodriguez L'eau (II), Victor Manuelle San Juan (II)). Perfume names of the third segment don't follow these tendencies. The personal names associated with these goods names are not enticing enough for consumers of that goods segment.

Famous actors' names are normally exploited for creating Bcomponent in a different way. There may be people who are still connected with the acting profession and have created their own perfumeries (Elizabeth Taylor (I), Christina Aguilera Unforgettable (I)). Producers may involve the names taking into consideration their popularity in certain artistic groups (Pavlova (II)), names of celebrities (Paris Hilton (II)). Some names are associated with perfumeries and well-known in jewellery business having some relatives in fine art (Paloma Picasso (I)). Names of inventors in physics (Fahrenheit (I)) or chemistry (Aura by Swarovski (II)) are used for creating a separate group of perfume names. Metonyms (Chloe (I), Anteus (I)) are engaged in the process of perfume name creation. Perfume names belonging to the third segment use anthroponyms in a specific way as they involve the advertising element of film stars' names which are neither the owners nor the 
founders of perfumeries. These cinema actors give their names as attractants to the perfumes, transforming names into semi brands (Laugh often by Reese Witherspoon (III); In bloom by Reese Witherspoon (III); Outspoken by Fergie (III)).

Within the perfume naming corpus, there are 50 toponyms which were created involving geographical names. The first goods segment grasps 39 names, the second goods segment includes 20 names. Moreover, geographical names are involved as components of naming complexes to indicate the company's headquarters (Paris (I); Paris Premieres Roses 2014 (I); Jimmy Choo Flash London Club (II); Roma (II); Tokyo Days (I); Tokyo Fashion (II); London Beat (II)). Perfume names which were formed with geographical names of different countries, regions, towns, districts, may be chosen according to the attractiveness of these toponyms. The attractiveness is connected with the positive associations of these toponyms: place of rest, entertainment, hustle-bustle life, conducive climate. The associative appeal prepares the positive acceptance of perfume and cosmetic goods with corresponding individual names (Fiji (I); Rio Glow (II); Granada (II), Cashmere Mist (I); Down Town (II); Santa Domingo (II)). The cases of naming synergy occur when different toponyms are connected and combined within one and the same perfume name (Cuba Copacabana (II); Cuba Hollywood (II); Cuba New York (I); Cuba Las Vegas (II)). Lexical units Eden, Paradise which are used in names Eden (I), Estee Lauder Beyond Paradise (I) bring consumers'(recipients') emotions in the seventh heaven. The involvement of anthroponym and toponym registers for creating perfume names is based on the basic knowledge of recipients. It improves the emotional and associative perception of B-basic components.

The appellative naming register is an inexhaustible source for creating perfume names. There are 301 names in the corpus. According to the segment differentiation of the appellative naming register, there are 152 names in the first, 98 in the second, and 51 in the third segment correspondingly. Appellative way of naming perfume goods requires the involvement of arbitrarily chosen words 
of lexical units (nouns): concrete general names and abstract notions which are characterized with different connotations. The words taken from the naming register and used for perfume name creation using the process of onymisation are divided into several groups. In the case of onomastic space investigation when attention is focused on the perfume goods names the traditional approach is connected with the notion of perfumonym thematic group having various integral semes $[8, \mathrm{p} .78]$. In the research, the central notion is connected with the lexico-semantic group. It gives a broader manoeuvre when perfume and cosmetic B-basic component formation is traced using onymisation of appellative lexis. If the scale of lexico-semantic groups is built up and this process happens in the boundary of perfume and cosmetic names originated from the appellative sphere, it is evident that the closest to the onym origin is the lexico-semantic group grasping social realities. These realities indicate gender difference (Woman (I)), social status and title (Princess (II); Gentlemen (I); Killer Queen (II); Lady Million (I)), as well as social relations (Best Friends Forever (II)). The relative lexico-semantic group indicates a person's psycho-emotional condition, expression of emotions and passion. Right in the centre of this lexico-semantic group, there is a person's emotional sphere (Guardians of Love (II); Love and Glamour (I); Obsession (II); Passion (I); Hypnose (II)). The logical continuation is the group that indicates the phenomena of the imaginary world which are connected with a person's emotional sphere (Angel (I); Miracle (II); Alien (II)). The psycho-emotional sphere is logically connected with person's intellectual-creative and cognitive activity, realized in different spheres of art (Jazz (I); Romance (I); Passion Dance (III)), in particular, in such a specific creative variant as the fashion design (Design (I); Little Black Dress (III)), travelling and sport (Journey (II); 212 Surf (I); 90210 Sport (II)), evaluation of external phenomena and qualities, situations (Beautiful (1); The Original (II); Just Precious (II); Lucky You (II); Lucky Darling (II); Curious (I)).

Evaluation of phenomena and situations comes from the objects of the real world, environment which have undergone the process of 
estimation. Real-world objects are made of substances of different physico-chemical nature. Therefore, lexico-semantic group "the substance" may be divided into several subgroups. The most attractive and expressive are names of precious stones and metals (Euphoria Liquid Gold (II); Precious Gold (II); White Diamonds (I); Rare Sapphires (III)). There is a separate subgroup of cloth names (Organza (I); Satin (II); Oriental Lace (II)), substances with strong physiological action (Poison (I), Opium (II), Elixir (III)) and original substances with specific properties (Irish Leather (II); Cool Water Coral Reef(II)).

The fundamental property of any substance is its colour. It means that the lexico-semantic group of colour naming is connected with the substance group (Red (I); Black Xs (I); Light Blue (I)). The perfume names are created using the vast level of botanical lexicon and terminology. According to the biological division, they are subdivided into floronyms (Sunflowers (I); Black Orchid (II)), herbonyms (English Fern (II)), dendronyms (Real Tree (III)), and different combinations of botanical terminology (Private Collection Jasmine White Moss (I); Elisabethan Rose (II); Orange Blossom (II); Flower of Immortality (II)). Botanical terminology words are logically connected with zoonyms belonging to the same concept of biology (Tigress Captivates (I); Angry Birds Rio (II)). The ninth lexico-semantic group which is differentiated in the appellative perfume and cosmetic name corpus is the group of temporal segmentation covering day and season differentiation (Today Tomorrow Forever (III); Fantasy Midnight (I); 212 Summer Eternity Night (II); Eternity Moment (II)). Differentiation of the naming register (its appellative part) caused the separation of nine lexicosemantic groups. Four groups are connected with the person and person's activity (social, psycho-emotional) and five groups are connected with the environment.

There are 168 names-borrowings in the boundary of perfume and cosmetic naming corpus. Borrowings create the third source of perfume names, where 87 names are connected with the first market segment, 56 - with the second, and 25 - with the third. The last 
figures indicate minimal expansion of borrowings in the sub corpus of the third segment. It may be explained by the fact that the third segment production consumers may not know foreign lexicon (mostly French) according to their level of education. Perfume nomination involving borrowings prevails in the case of the first segment perfume goods. Perfume tradition was originated in France, the country where the best quality perfumes are manufactured which is why French nomination confirms the high quality and refinement of goods nominated. French perfume names are separated into different lexico-semantic groups of appellative origin, representing perfume and cosmetic goods in all their varieties. The lexicosemantic group of social realities is represented with names: Femme (III) - "woman"; L'Homme (I) - "man"; L'Homme Libere (I) "free man". The lexico-semantic group of person's psychoemotional state is formed with names: Amor-Amor (I) - "love, love"; Magie Noire (I) - "black magic"; J'Adore (I) - "I adore". There are names connected with phenomena of imaginary world (Ange on Demon (I) - "angel or demon"), display of creative activity (Hot Couture (I) - "high fashion"; La Petite Robe Noir Couture (I) - "a little black dress of fashion"), substances (Omnia Amethyste (I) "magic amethyste"; Belle D'Opium (I) - "wonderful opium"), botanical terminology (Mon Jasmin Noir (I) - "my black jasmin"; Fleur d'Intendit (I) - "a flower forbidden"). There are names created involving toponyms (Champs Elysees (I) - "Elysian Fields"; Parisienne (I) - "Parisian woman"). The Italian language is used for creating perfume names (Dolce Vita (I) - "sweet life"; Acqua Di Parma Rosse Nobile (II) - "Parm's water made of noble rose"), Portuguese language is used here too (Escada (I) - "stairs"). Sanskrit is the source of some names too (Shalimar (I); Samsara (I)).

Artificially created words form the fourth source of perfume and cosmetic names. Some names are formed on the principle of sound imitation (Purr (II); Meow (II)). The creation of the name Lancôme has an interesting history. The company was founded in 1935 by Armand Petitjean, a well-known perfumer and cosmetician. One of the employees put forward the name "Lancosme" (where the letter $s$ 
is mute), which was a castle name in region Loiret. The name was approved but with some changes. A circumflex symbol appeared over $o$, letter $s$ disappeared. Circumflex appeared in many perfume names a bit later. Another example is the name of cosmetic company L'Oreal which was created artificially by founder Eugene Schueller. In 1907 he invented synthetic pigment for hair dying. The name $L^{\prime}$ Oreal attracted his attention due to its harmonious sounding. These words are known to be very difficult for creation because traditional methods of word-formation are not applied to them. When a new word is being created for nominating a new object, a nominator is under the influence of subjective correlation between sounds and objects [9, p. 214].

Toilet water naming corpus contains 371 names where 52 names belong to the anthroponymic register (30 names are in the first segment, 22 are in the second one). Toponymic register includes 44 names and they are divided between the first segment (15 names) and the third segment (29 names). Appellative lexicon was the source of 149 names which are separated between the first segment (50 names), the second segment (61 names) and the third segment (38 names). Borrowings were used for creating 126 names. The first segment comprises 77 names, the second segment -39 , and the third one - only 10 . There is only one name which was created by involving the artificially created word $(O$ de Lancôme (I)). There is a certain resemblance in the ways of forming the names of toilet waters and perfumes when an anthroponymic source is involved. In the case of appellative lexicon usage, the absence of lexico-semantic group of zoonyms indicates the narrowing of the naming register. There are cases of naming synergy within B-basic naming components when botanical terminology and colour indication are combined (Purple Lilac (I)). Eau de toilette names formed involving borrowings demonstrate traditional usage of French lexemes (Egoiste (I); L'imperatrice (I); Pour Homme (I); Pur Blanca (III)).

Eau de cologne naming corpus contains 169 names and has some specific features. The first feature demonstrates the absence of eau de cologne names belonging to the third segment. Moreover, there are 
no artificially created words. Anthroponyms comprise 91 names (62 names belong to the first market segment; 29 names are connected with the second segment). Toponyms are used to form 19 names ( 2 are connected with the first segment and 17 with the second one). Appellative lexemes are used to create 21 names (10 belong to the first segment, 11 are connected with the second). Traditional borrowings occur in 38 names (20 are in the first and 18 are in the second segments). Anthroponyms create B-basic components of eau de cologne in the same way as in the case of perfume and eau de toilette names. In the name corpus of eau de cologne, B-basic component doesn't use traditional toponym Paris. The appellative lexemes used for B-basic component creation are classified into 9 lexico-semantic groups. All of them demonstrate explicit or implicit masculine features (masculinity) confirming the fact that eau de cologne is produced for men. The features of "masculinity" are represented explicitly in the social reality lexicosemantic group (Gentleman (I)); Tribute for Men (II), Bod Man Tresh Guy (II); Bod Man Warrior (II)). Masculinity may also be traced in the names reflecting creativity (Mustang Sport (I); Road Runner (II); Surf (I)), in the boundary of substance lexico-semantic group (Rocky Man Silver (II); Adrenaline (II)) and the lexicosemantic group of zoonyms (Stallion (II); Golden Cougar (II)). In addition, masculinity features may be found in the names created as a result of borrowing involvement. They are mostly of French origin where corresponding masculine lexemes are used in the structure of names (Hypnose Homme Cologne (II); Anthracite Pour L'Homme (II); Aqua Pour Homme (I); L'Homme (I); La Nuit De L'Homme (I)). There is a specific German borrowing which was the first name of eau de cologne as new goods (№4711 Kölnisch wasser (II)). Representation of masculinity in eau de cologne names is realized through usage of the combination of anthroponyms with appellatives (Bulgari Man in Black (I); Lauder for Men (I); Versace Man (I); Versace L'Homme (I); Versace pour Homme (I)), or anthroponym combination (Versace Eros (I)) where lexeme Eros is a name of the God of love in Ancient Greece. 
The investigation of cosmetic (in fact make-up) names in the boundary of naming register, which gives names-to-be for corresponding goods, demands attentive and detailed analysis considering all extralinguistic features of the objects nominated. Make-up goods, perfumes, eau de cologne, and eau de toilette are used for changing the complexion or separate parts of the face, distinguishing skin defects, giving face parts attractive, popular colour or shade according to the tendencies of vogue. It is reflected in B-basic component of naming complex where the substance nature and specification of make-up, for example, underlying waterproofness of mascara (Hypnose Star waterproof (II)) or its property to separate every lash (inimitable-intense) volume-length curl separation (II)), underlying sexual glance using the colour and texture of the substance (Sexy Pulp Lash Plumping Black (I)). Names of mascara get descriptive and technological character; furthermore, their utility is emphasized. It is caused by the necessity of giving detailed information to the user within the boundary of B-basic component. It provides the possibility of obtaining appropriate information about the goods.

Name utility originates from the physical-chemical characteristics of make-up. They are manifested in B-basic component keeping the consumer informed about colour (24k Golden Black 87626 (III)) and texture (Diorshow Iconic Overcurl (I)). In the case of eye shadow, the colour characteristic is indicated (Intense Color Matte Pop Violent (I)), the shade effect and its longevity are described as well (Ultra-Long-Lasting Cream (I); $12 \mathrm{H}$ waterproof (I)). Lipstick names have a colour description in the first place (Color Trend Deep Red 30133 (III)), optical effect may also be indicated (Super Lustrous (II); Color Fever Shine (II)). Lip gloss names indicate make-up characteristics (Extralasting Continuous Copper (III)), the impact on the organism (Hydra beauty nutrition (I)). The utility is traced in the names of nail wear where colour nomination prevails (Color trend Vixen 29982 (III)), as well as cover hardness (Nail experts Mineral fix (III) and optical effect (Nail experts Pearl Shine (III)). 
The common feature of all make-up names is the involvement of somatisms as parts of B-basic components. They specify the parts of the body for applying corresponding make-up. That type of indication for perfumes is excessive and unnecessary. In nail polish names are sometimes represented with lexeme nail within B-basic component (Nail experts 24k gold strength (III); Nail Lacquer (III)). Lipstick names use somatism lip(s) (Dior Addict Lip Polish (I)), as well as mascara (Eye Lash; Turbo Lash (I); Eye to kill (I)). Mascara naming corpus has 88 names, 11 names are of an anthroponym origin, 10 are connected with the first segment, 1 -with the second. Within the mascara naming corpus, no toponyms and artificially created words were observed.

Utility aspect occupies a leading nominative position in the case of make-up. It causes a decrease in anthroponymic names and an increase in appellative names. There are 71 names of appellative origin that are divided between three market segments (29 (I), 46 (II), 17 (III)). There are no names connected with lexicogrammatical groups of social realia, botany and zoology. Eyeshade naming corpus grasps 78 names, among them there are 7 anthroponyms (5 (I), 2 (II)), 1 toponym (I segment), 5 borrowings (I segment), 59 appellatives (18 (I), 10 (II), 31 (III)). Names of appellative origin show utility tendency. The biggest subgroup is connected with colours and has 31 names. All of them are connected with the third segment (Precious Glimmer Deep Purple 64355 (III)). The lipstick naming corpus has 198 names. There are only 6 anthroponymic names. All of them are in the first segment whereas there are no toponymic names at all. There are three borrowings. Appellative names are the most numerous (185 of them). They are spread between three market segments (16 (I), 9 (II), 164 (III)). The lip gloss naming corpus contains 110 names (7 anthroponyms, 2 borrowings, and 101 appellatives). As it was in the lipstick naming corpus, the lip gloss naming corpus has a big colour lexico-semantic group (53 names). It conforms to utility tendency in nomination (Perfect Kiss Bodly Red 88302 (III)). Names of nail polish (124 names) are used involving anthroponyms (5 names), appellative 
(119 names), where colour indication lexico-semantic group prevails (93 names: Nail wear pro Pastel Pink 82636 (III); Shiny Pastel Pink (I)). Face foundation naming corpus has 132 names with 16 ones of anthroponymic origin, all of them belonging to the first segment (Dior Prestige White (I)) and 18 borrowings divided between two segments (12 (I), 6 (II); Les Beiges (I); Color Ideal (II)). Appellative names (98) create the biggest portion with prevailing colour indication (Magi X Natural Beige 89383 (III)). The similar tendency may be observed in the powder naming corpus (60 names), color corrector cream (18 names) and blush (20 names). Nourishing face creams don't belong to the perfume and the make-up as they are next to the medicine but they improve the physiological condition of skin and don't mask the defects without treatment. What is more, the decorative effect is connected with make-up only. Nourishing face cream naming corpus grasps 168 names; 8 names anthroponyms, 14 are borrowings, 145 are appellatives (32 (I), 42 (II), 71 (III)). All of them reflect utility naming tradition. Lexico-semantic group of substance names underlines components of creams (AOC Olive Oil (I); Organic Oats (I); Solutions Youth Minerals (III)). Some types of creams are used for the separate parts of the body that are indicated in B-basic components involving lexemes-somatisms (Face and Body Comfort (I); Caring Hand Cream (III); Hand and Nail Treatment (II)). One of the definite ways of representing utility in the process of nourishing cream nomination is the lexico-semantic group of physiological action. It underlines the biological and the physiological effect of creams (Expert firming (I); Global Lift [Pro-GEN-in] (II); Care and Fresh hydrating (III)).

Conclusion. Perfume-cosmetic naming register created within the corpus of lexemes consists of four groups. These groups were distinguished according to the ways of name creation. The leading group was separated involving the way of transonymisation. All these names are onyms. They are divided into anthroponyms and toponyms. The second group grasps names created after onymisation and includes nine lexico-semantic groups having appellatives. The third facultative group contains the names-borrowings (mostly of 
French origin). The fourth group consists of artificially created words. It is essential to mention that social stratification is reflected in the naming perfume and cosmetic register in various ways. It may be an extralinguistic way when perfume and cosmetic goods are separated into three market segments (the most expensive products (I), the reasonably priced goods (II), consumer goods (III)). Formally this differentiation correlates with A-brand naming component. It marks corresponding goods according to the brand status. Social stratification may be represented in a linguistic way and correlates with B-basic naming component which includes lexical unitsfragments of naming components. Social stratification may also be represented in an explicit way involving lexemes of status semantics (Princess, Gentleman, Queen, Lady) and gender differentiation (Girl, Woman, Man, Boy). Implicit stratification is presented involving personal names (personyms) - symbol of high social status (Dolce and Gabbana, Dior, Paris Hilton, Elizabeth Taylor) or using toponyms associated with hustle-bustle life of a city (Paris, London, New York, Las Vegas). Social stratification is represented implicitly involving lexemes of luxurious substances, metals and stones (Gold, Diamond, Pearls, Sapphires, Platinum, Silver). Social stratification reflection may be investigated in details using the method of vocabulary definitions and separating integrated semes.

\section{REFERENCES}

1. Harrison, M. E. (2010). The Scent Word: Context, Intrigue, and the Problem of Olfactory Literacy. Fragrances - Supplement to Household and Personal Care Today, 1, 6-10 [in English].

2. Ivanova, K.A. (2005). Copywriting: the secrets of creating advertising and PR texts [Kopirajting: sekrety sostavlenija reklamnyh i PR-tekstov]. SPb.: Piter, 144 s. [in Russian].

3. Jones, G. (2011). Globalization and Beauty: A Historical and Firm Perspective. EURAMERICA, 41(4), 885-916 [in English].

4. Kohli, C. (1997). Observations: Creating Effective Brand Names: A Study of the Naming Process. Journal of Advertising Research, 37 (1), 6775 [in English]. 
5. Merskin, D. (2007). Truly Toffee and Raisin Hell: A Textual Analysis of Lipstick Names. Sex Roles, №56, 591-600 [in English].

6. Platon (1968). Compositions in three volumes [Sochinenija v 3-h tomah]. T. 1. Moscow : Nauka, 670 s. [in Russian].

7. Rozhdestvenskiy, Yu. V. (1975). The theory of language personality. Essays on the history of linguistics. [Teoriya yazykov antichnosti. Ocherki po istorii lingvistiki.]. Moscow: Nauka, 32-110 [in Russian].

8. Sotnikova, E. A. (2006). Onomastic space of perfumery names in Russian [Onomasticheskoe prostranstvo nazvaniy parfyumernoy produktsii $\mathrm{v}$ russkom yazyke]: dis. na soiskanie nauch. stepeni kand. filol. nauk: spets. 10.02.01 "Russkiy yazyk". Elets: Eletskiy gos. ped. universitet, 259 s. [in Russian].

9. Vandries, Zh. (2001). Language. Linguistic introduction to history. [Jazyk. Lingvisticheskoe vvedenie v istoriju]. Moscow: Editorial URSS, 408 s. [in Russian].

10. Walker, R. (2012). A Challenging Global Climate for Fragrances. Global Cosmetic International, November, 26-29 [in English].

Дата надходження до редакції - 31.10.2021 Дата затвердження редакцісю - 15.11.2021 